

\section{Acanthosis nigricans benigna}

\author{
Стоян ПаВАов
}

\author{
Клиника по Дерматология и Венерология, \\ УМБАА „СЪ. Марина”, Варна
}

\section{Pesłome}

Acanthosis nigricans (AN) е pяgkо Вроgено ики прugобито Вторично кожно заболяВане, характеризиращо сес потьмняВане (хиперпигментация) и уgебеляВане (хиперкератоза) на kожата. Ангажирани са симетрично гънките: В поgмишницата (akcusama), слабините и заgната част на Bpama. Поgразgеля се на gоброкачестВен („pseudoacanthosis nigricans“ ) u змокачествен AN.

Преgставя се смучай на 43-гоgишна жена с AN - симетрични пигментирани плаки с папиломатозна nовърхност B akcusume, тила, гърба на хоgилата, на фона на кминични прояви на обезитас III степен (ИТМ $>40 \mathrm{kz} / \mathrm{m} 2$ ) и инсулинорезистентен gиабет с наg 10-гоgишна gавност. Изк^ючени са хипотиреоияизъм, акромегалия, овариална поликистоза и болест на Кушинг. НапраВен е скрининг за Висцерална неоплазия. Фамилната анкета не откриВа изява на AN cpeg близкume.

AN най-Вероятно се причинява om фakmopu, koumo стимулират пролиферацията на кератиноцитите $B$ enugeрмиса и на фибробластите $B$ geрмата. При gоброкачествената форма на AN, makъB фakmop Вероятно е инсулинът или инсулинопоgобният растежен фактор (IGF), kоüто стимулира растежа на епugeрмалните kлеmku. Onреgелена роля играят и peuеnторите на тирозин киназата (рецеnтора на еnugeрмален растежен фактор или рецеnтора на растежен фактор на фибробластите). При високи концентрации, инсулинът упражняВа мощен промиферативен ефект, чрез свързВане c Bucok aфuнumem kbM IGF-1 peuеnmopume. B gonb九нение, нивата на сBобоgен IGF-1 могаm ga бъgam повишени при пациенти сьс затльстяване с хиперинсулинемия, kоeто воgu go ускорен клетъчен растеж и guференциация. ПреgстаВеният случай е и^юстративен за ряgка gерматоза, която може ga бъgе Вродена или паранеопластичен gермадром.

Kлючовu gyмu: Acanthosis nigricans, паранеопластичен синдром, инсулинова резистентност

\section{Acanthosis nigricans benigna}

\author{
Stoyan Pavlov
}

\author{
Clinic of Dermatology and Venereology, \\ University Hospital "St. Marina", Varna
}

\begin{abstract}
Acanthosis nigricans (AN) is a rare congenital or acquired secondary skin disease characterized by darkening (hyperpigmentation) and thickening (hyperkeratosis) of the skin. The folds are symmetrically involved: plaques with the morphological characteristics of AN are found in the armpit (axilla), groin and back of the neck. It is subdivided into benign ("pseudoacanthosis nigricans") and malignant AN.

We present a case of a 43-year-old woman with AN with localized symmetrically pigmented plaques with a papillomatous surface in the axils, nape, back of the feet. The patient has clinical manifestations of grade III obesity (BMI $>40 \mathrm{~kg} / \mathrm{m} 2$ ) and insulin-resistant diabetes with a duration of more than 10 years. Hypothyroidism, acromegaly, polycystic ovary and Cushing's disease are excluded. Screening for visceral neoplasia was performed. The family survey did not reveal any manifestation of AN among the relatives.

AN is most likely caused by factors that stimulate the proliferation of keratinocytes in the epidermis and fibroblasts in the dermis. In the benign form of AN, such a factor is probably insulin or insulin-like growth factor (IGF), which stimulates the growth of epidermal cells. Tyrosine kinase receptors (epidermal growth factor receptor or fibroblast growth factor receptor) also play a role. At high concentrations, insulin exerts a potent proliferative effect by binding with high affinity to IGF-1 receptors. In addition, free IGF-1 levels may be elevated in obese patients with hyperinsulinemia, leading to accelerated cell growth and differentiation. The case presented is illustrative of a rare dermatosis, which may be congenital or a paraneoplastic dermadrome.
\end{abstract}

Keywords: Acanthosis nigricans, paraneoplastic syndrome, insulin resistance

\section{Кореспонденция:}

Доц. g-р Стоян ПаВлов, gм

e-mail: stoyanpavlov@abv.bg

\section{Correspondence:}

Assoc. Prof. Stoyan Pavlov, MD, PhD

e-mail: stoyanpavlov@abv.bg 


\section{Bъßеgенuе}

Acanthosis nigricans (AN) е pяgkо Вроgено ими прugобито Вторично кожно заболяВане, протичащо с потьмняВане (хиперпигментация) и уgебеляВане (хиперкератоза) на kожата, ангажиращо симетрично гънките: 8 поgмишницата (akcuлата), слабините и заgната част на Врата. Първият случай на AN е оnисан om Paul Gerson Unna при болен с „разпространена хиперпигментация и папикоматозна хипертрофия на кожата“. Терминът AN, преgложен оm Unna, е използВан през 1891 г. om Pollitzer u Janovsky B техния „International Atlas of Rare Skin Diseases" [1]. Понастоящем заболяВането се поgразуеля на gоброкачестВен и злокачестВен AN. ЗлокачестВеният AN е gермаgром на Висиерална неоплазма. ДоброкачестВеният AN - m.н. „pseudoacanthosis nigricans“ се acouиuра с реguца Вроgени u nрugобити заболяВания [2].

\section{Mamepuan u memogu}

Клинични метоgu: снемане на gерматологична анамнеза и cmamyc, фамилна анамнеза и анkета за изяВени наслеgстВени gерматози. Консултации сьс специалисти: енgокринолог, гинеколог, гастроентеолог, неВролог, офталмолог. Паракминични изслеgВания: ПКК с ДКК, кръВна захар, урея, креатинин, АСАТ, АЛАТ, ГГТП. Хормонален профия: СТХ, ТХ,ТЗ,Т4, geхиgроепиандростерон, анgростендион, gexugpoenuaнgростерон сулфат. Мuкробиологично и микологично изслеgване на намазки оm kожа и мигавица. Рентгенографско изслеgВане на глаВа и гръgна kлетка.

\section{Резулmamu}

Преgставя се случай на 43-гоgишна жена с AN, на фона на клинични прояви на обезитас и инсулинорезистентен

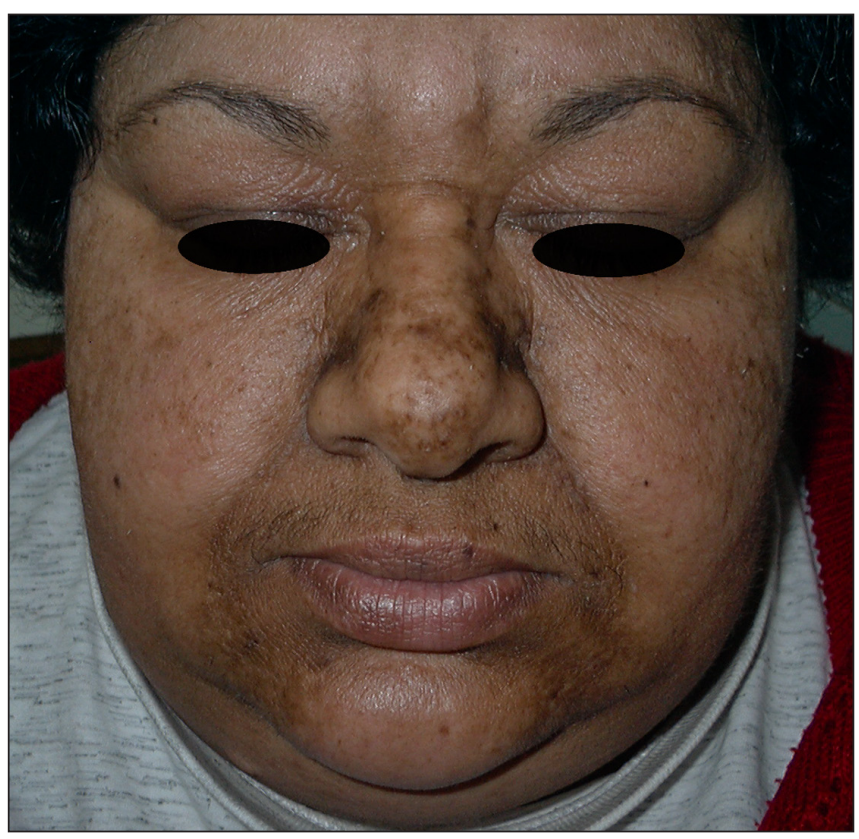

Фuгура 1. Хиперхромни кафеникаßu макули

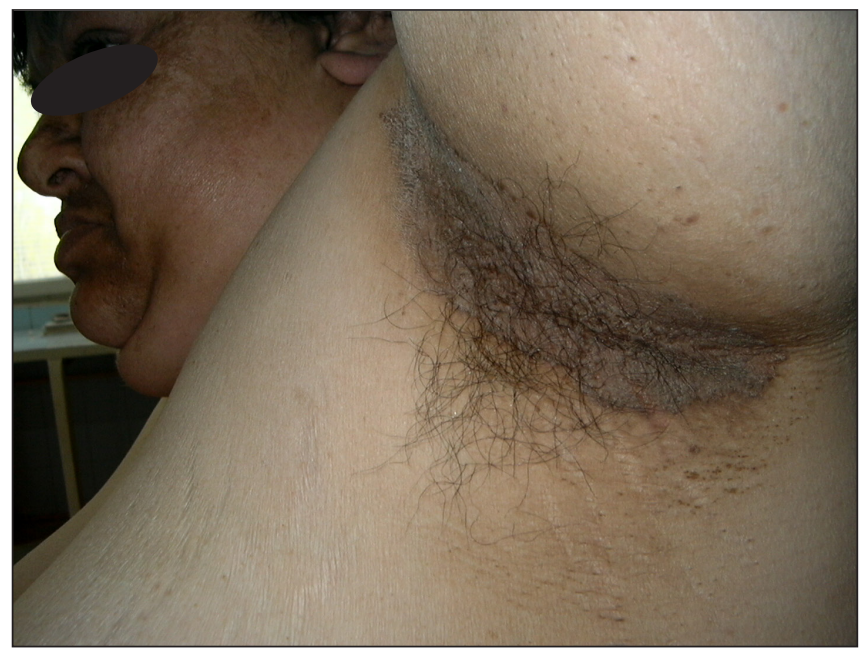

Фuгура 2. КафеникаВu nмаku с фино налобена, напоgобяВаща kaguфе nanuломатозна повърхност (I)

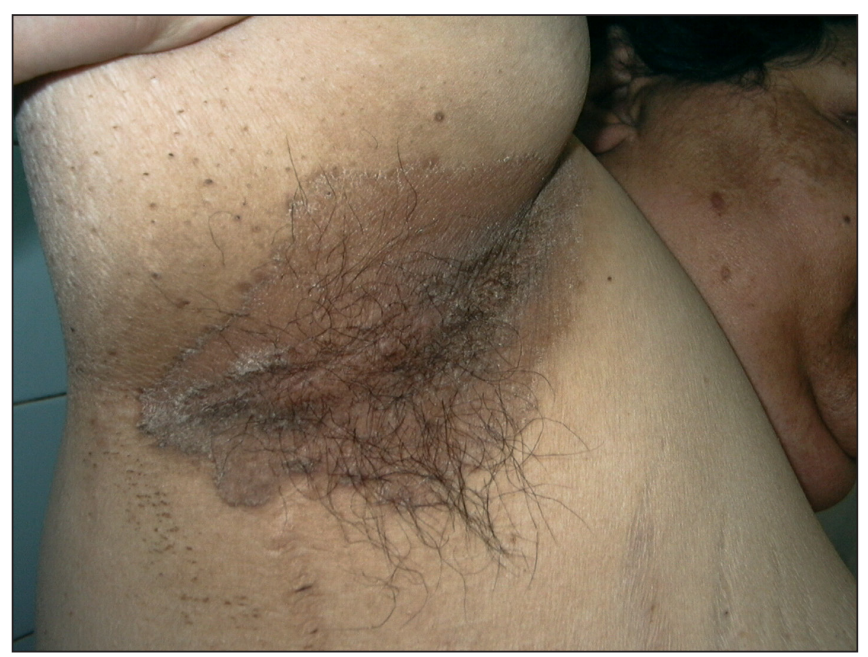

Фuгура 3. КафеникаВu nмаku с фино напобена, напоgобяВаща kaguфе nanuломатозна повърхност (II)

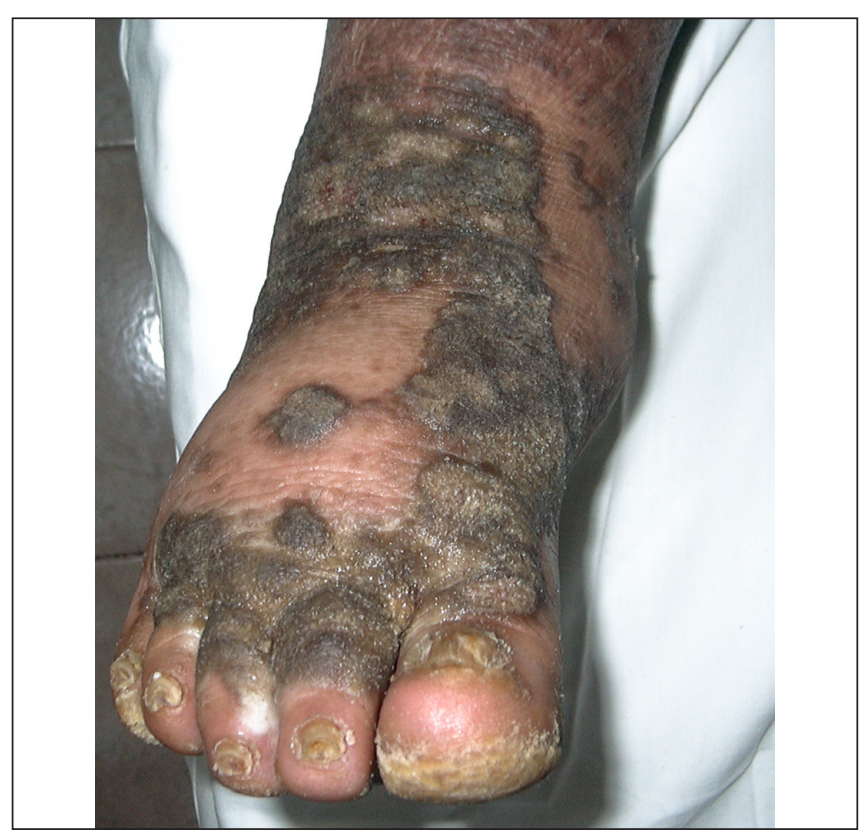

Фигура 4. Конфмуиращи скВамозни пnаkи 
guабет. Изк^ючени са хипотиреouguзъм, акромегалия, овариална поликистоза и болест на Кушинг. НапраВен е скрининг за Висиерална неоплазия, не са отkрumи тумори на бял gроб, гастроинтестинален mpakm, млечна жлеза, маточна шuӣka u agнekcu. Фамилната aнkema не omkpußa изяВа на AN среg близките. Om geрматологичния сmamyс: nатологичните промени ангажират кицето, симетрично akcuлите, ингВиналните гънки, тияа. Кожата на мицето - по гърба на носа, назолабиалните гънkи и челото е изпъстрена om хиперхромни кафеникаßи макули (Фигура 1). В областmа на akcuлите и тила са мокализирани кафеникаВи плаkи с фино налобена, наnogобяВаща kaguфе папиломатозна повърхносm (Фuгурu 2 и 3). По гърба на хоgиката се намират конфмуиращи скВамозни плаки (Фигура 4).

\section{Обсъжgане}

AN e uнgukamußна кожна прояВа на множество поgлежащи заболяВания и В заВисимост от това, поgразgелен на 7 muna:

1. Асоцииран с обезитас: най-често срещан, прояВен Във Bcяkа Възраст, но обикноВено при Възрастни; съчетаßа се с инсулиноВа резистентност.

2. Асоцииран със синдроми (Таблица 1): хиперинсулинемия, синдром на Кушине, овариална поликистоза, тотална мunogucmрофия, синgром на Crouzon u gp.

3. Доброкачествен AN: nо гърба на ръцете и хоgиката се образуВат п^ьтни, несърбящи с нераВна, поgобна на kаguфе nовърхност пигментирани плаки. Засегнати са хората с тьмна и мургаВ на цВят kожа.

4. ^екарстВено инgуциран: меguкаменти kamo нukотинова kиселина, kорmukocmepougu, инсулин, хормонотерапия могат ga npeguзBukam AN.

5. Вроgен gоброкачествен AN: автозомно gоминантно унаслеgяВан, може ga се прояВи ВъВ всяkа еgна Възраст.

6. Малигнен AN: неопмазма на ГИТ в 90\%, най-често стомашен карцином.

7. Смесен mun AN: болни с еguн mun AN могаm ga разВияm нови мезии при прояВа на ноВа причина, например пациенти с обезитас uнgуuиран AN nрu пояВа на неопмазма [3].

AN най-Вероятно се причинява om фakmopu, koumo стимулират пролиферацията на кератиноцити $B$ enugepмиса и на фибробласти В gермата [5]. При gоброкачестВената форма на AN, makъB фаkmор Вероятно е инсулинът или инсулинопоgобният растежен фаkmop (IGF), kоūmo cmuмулира растежа на еnugeрмалните kлетku [6-7]. Onреgелена роля играят и рецеnторите на тирозин kuназата (рецеnтора на еnugeрмален растежен фаkmор ими рецеnтора на растежен фаkтор на фибробластите). При Вuсоkи концентрации, инсулинът упражняВа мощен промифератиВен ефеkm, чрез свързВане с Bucok афинumem kbM IGF-1 peцenmopume [1].
Таблица 1. Сuнgромu, асоциuрани с AN [4]

\section{І. Синдроми с инсулинова резистентност}

- Акрална хипертрофия с мускулни крампи

- Акромегалия

- Amakcuя - телеангиekmaзия (Сuнgром на Louis-Bar)

- Сuнgром на Alström

- Cuнgром на Cushing

- Захарен guaбem mun 2

- Гонаgна guсфункция

- Овариална хипертрихоза

- Поликистоза на яйчниците (Сuнgром на Stein-Leventhal)

- Cuнgром на Cushing

- Синgром на Rabson-Mendenhall

- Leprechaunism

- Nunogucmpoфuя:

- Сuнgром на Lawrence-Seip - конгенитална мunogucmрофия cbc захарен guабет

- Сuнgром на Seip-Berardinelli - конгенитална генерализирана ^onogucmрофия

- Сuнgром на Kobberling-Dunnigan - фамилна парциална мunogucmpoфuя

- MORFAN (Mental retardation, overgrowth, remarkable faces, and acanthosis nigricans)

- Сuнgром на Prader-Willi

- Tun А синдроми на инсулинова резистентност

(Хиперандрогенизъм, инсулинова резистентност и AN cumgpom, HAIR-AN)

- Tun B синдроми на инсулинова резистентност

- Сuнgром на Hashimoto

- Scleroderma

- Cuнgpom на Sjögren

- Systemic lupus erythematosus

- Tun C синдром на инсулинова резистентност

\section{II. Сuнgромu c geфеkm на рецеnторите за растежен фаkmop (FGFRDS)}

- Cuнgром на Beare-Stevenson (cutis gyrata syndrome)

- Сuнgром на Crouzon

- Сuнgром на ахонороплазия с AN (SADDAN)

- Танатофорична guсnıазия

\section{III. Другu acouuauuu}

- ДоброкачестВена енцефалопатия

- Вроgена аgренална хиперп^азия

- Cuнgром на Costello

- Хепатолентикуларна gегенерация (Болест на Wilson)

- Синgром на Hirschowitz

- Xunomupeouguзbm

- Сuнgром на Kabuki

- Ихтиоза с хипогонаguзъм (Сuнgром на Rud)

- Пьрвична билиарна цироза 
B gonълнение, ниВата на сВобоgен IGF-1 могаm ga бbgam повишени при пациенти със затльстяВане с хиперинсулинемия, koemo Bogu go ускорен клетьчен растеж и gиференциация [4].

\section{Заключение}

Onuсаният случай на AN преgставя специфични промени nо kожата, koumo могаm ga бъgam използВани kamo guагностичен маркер за неопластични, прugобити и Bpogeни енgокринни заболяВания, нарушения В обмяната на Веществата, генетично gетерминирани geфеkmu $B$ kлетъчната пролиферация и gиференциация.

\section{Библиография}

1. Popa M-L, Popa AC, Tanase C, et al. Acanthosis nigricans: To be or not to be afraid. Oncol Lett. 2019;17(5):4133.

2. Kubicka-Wołkowska J, Dębska-Szmich S, Lisik-Habib M, et al. Malignant acanthosis nigricans associated with prostate cancer: a case report. BMC Urol. 2014;14(1).
3. Das A, Datta D, Kassir M, et al. Acanthosis nigricans: A review. J Cosmet Dermatol . $2020 ; 19(8): 1857-65$.

4. Higgins SP, Freemark M, Prose NS. Acanthosis nigricans: a practical approach to evaluation and management. Dermatol Online J. 2008 Sep 15;14(9):2.

5. Koyama S, Ikeda K, Sato M, et al. Transforming growth factor-alpha (TGF a)-producing gastric carcinoma with acanthosis nigricans: An endocrine effect of TGF $a$ in the pathogenesis of cutaneous paraneoplastic syndrome and epithelial hyperplasia of the esophagus. J Gastroenterol. 1997 Feb;32(1):71-7.

6. Kong AS, Williams RL, Rhyne R, et al. Acanthosis nigricans: high prevalence and association with diabetes in a practice-based research network consortium - a PRImary care Multi-Ethnic Network (PRIME Net) study. J Am Board Fam Med. 2010 Jul;23(4):476.

7. Karadağ AS, You Y, Danarti R, et al. Acanthosis nigricans and the metabolic syndrome. Clin Dermatol. 2018 Jan 1;36(1):48-53. 